Article

\title{
In situ synthesis of Fe-N-C catalysts from cellulose for hydrogenation of nitrobenzene to aniline
}

\author{
Hao Wang a,t, Xiaohao Liu a,t, Guangyue Xu a , Ziwei Guo a, Ying Zhang a,b,* \\ a Department of Chemistry, University of Science and Technology of China, Hefei 230026, Anhui, China \\ b Dalian National Laboratory for Clean Energy, Dalian 116023, Liaoning, China
}

\section{A R T I C L E I N F O}

\section{Article history:}

Received 28 April 2019

Accepted 27 May 2019

Published 5 October 2019

\section{Keywords:}

Co-pyrolysis

Iron

Nitrogen-doped

Carbon

Hydrogenation

\begin{abstract}
A B S T R A C T
Owing to Fe being the most abundant and least expensive transition metal on the earth, the utilization of Fe-based catalysts for catalytic hydrogenation has attracted worldwide attention. In this work, a series of N-doped C supported Fe catalysts (Fe-N-C) were prepared by co-pyrolysis of cellulose and ferric chloride under ammonia atmosphere. Characterization methods such as elemental analysis, atomic absorption spectroscopy, nitrogen adsorption-desorption isotherms, transmission electron microscopy, high-resolution transmission electron microscopy, X-ray diffraction, and X-ray photoelectron spectroscopy were carried out to explore the physicochemical properties of the catalysts. Using hydrogenation of nitrobenzene as a model reaction, the catalysts prepared at different pyrolysis temperatures displayed different activities. Fe-N-C-700 exhibited the best activity among these catalysts, with the yield of aniline being up to $98.0 \%$ under $5 \mathrm{MPa} \mathrm{H}_{2}$ at $120{ }^{\circ} \mathrm{C}$ after $12 \mathrm{~h}$. Combined with the results of catalyst characterization and comparative tests, the transformation of Fe species and the generation of $\mathrm{N}$-doped $\mathrm{C}$, especially graphitized $\mathrm{N}$-doped $\mathrm{C}$, in the catalyst may be the main factors affecting the activity. A kinetic study was carried out and the apparent activation energy was obtained as $31.53 \mathrm{~kJ} / \mathrm{mol}$. The stability of the catalyst was also tested and no significant decrease in the activity was observed after 5 runs.
\end{abstract}

(C) 2019, Dalian Institute of Chemical Physics, Chinese Academy of Sciences. Published by Elsevier B.V. All rights reserved.

\section{Introduction}

Precious metals are widely used as catalysts for various reactions [1-5]. However, their high prices and limited availabilities have sparked interest in non-precious-metal catalysts. Therefore, finding an abundant and efficient catalyst to replace precious metals has become one of the most essential tasks in the field of catalysis [6-9]. In this context, Fe is the cheapest metal and is widely distributed on the earth, accounting for $4.75 \%$ of the crustal content [10]. Further, Fe-based catalysts have showed excellent activities in ammonia synthesis [11],
Fischer-Tropsch synthesis [12], and selective reduction of $\mathrm{NO}_{x}$ [13]. In recent years, Fe-N-C, in which Fe is supported by or incorporated with $\mathrm{N}$-doped $\mathrm{C}$, has been reported as an inexpensive and efficient catalyst because of its good catalytic properties in various typical Pt-catalyzed reactions, such as oxygen reduction reaction [14-18], $\mathrm{CO}_{2}$ electroreduction [19], hydrogen evolution reaction [20-24], fine chemical synthesis, and, especially, catalytic hydrogenation [25-32]. There are many methods available for preparing $\mathrm{Fe}-\mathrm{N}-\mathrm{C}$, including soft and hard template methods [33,34], chemical vapor deposition [35,36], sol-gel method [37], plasma treatment [38], microwave

\footnotetext{
* Corresponding author. Tel: +86-551-63603463; Fax: +86-551-63606689; E-mail: zhzhying@ustc.edu.cn

+ These two authors made equal contributions to this work.

This work was supported by the National Natural Science Foundation of China (51876200, 21572213), and the DNL Cooperation Fund, CAS (DNL180301).

DOI: S1872-2067(19)63416-9 | http://www.sciencedirect.com/science/journal/18722067 | Chin. J. Catal., Vol. 40, No. 10, October 2019
} 
synthesis $[39,40]$, and pyrolysis, among which pyrolysis is the most common and the simplest method. In 1964, Jasinski [41] reported for the first time the use of cobalt phthalocyanine as a non-noble-metal oxygen reduction catalyst. Then, there were a few reports on the synthesis of Me-N-C catalysts by pyrolysis of organic transition metal macrocycles [42-44]. By synthesizing Me-N-C via pyrolysis of macrocyclic Fe-N organic compounds and organometallic framework complexes, relatively stable $\mathrm{Fe}-\mathrm{N}$ coordination structures can be obtained. However, the preparation process is complicated and the cost of raw materials is high. Therefore, simple co-pyrolysis of transition metal salts (such as $\mathrm{FeCl}_{3}, \mathrm{Fe}\left(\mathrm{NO}_{3}\right)_{3}, \mathrm{Fe}(\mathrm{Ac})_{2}$, and $\mathrm{FeC}_{2} \mathrm{O}_{4}$ ), $\mathrm{N}$-containing compounds (such as $\mathrm{NH}_{3}, \mathrm{~N}_{2} \mathrm{H}_{4} \cdot \mathrm{H}_{2} \mathrm{O}, \mathrm{CO}\left(\mathrm{NH}_{2}\right)_{2}$, and $\mathrm{C}_{3} \mathrm{H}_{3}\left(\mathrm{NH}_{2}\right)_{3}$ ), and $\mathrm{C}$ carriers (such as Vulcan, ECP, carbon nanotubes, and graphene) was carried out to synthesize Fe-N-C catalysts $[45,46]$. Despite some progress, it is still meaningful to develop simpler methods and use more readily available materials to prepare the catalysts.

The hydrogenation of nitrobenzene to aniline is an important reaction since aniline is a versatile organic raw material and a fine chemical intermediate that is widely used in pesticides, pharmaceuticals, dyes, and other industries $[47,48]$. Researchers have been focusing on the hydrogenation of nitrobenzene to prepare aniline for decades. At present, the catalysts for the hydrogenation of nitrobenzene mainly include noble metals (Pt [49,50], Pd [51], Ru [52-54], Au [55], etc.). Although precious metals can catalyze the hydrogenation of nitrobenzene under milder conditions, they are not widely used in large-scale industrial production owing to the high costs. Therefore, it is attractive to prepare an efficient Fe-based catalyst with high activity and high stability that offers easy separation and reusability. Baylor et al. [56] carried out pioneering work by using Fe-phen catalysts prepared by pyrolyzing Fe-phenanthroline complexes on a support at $800^{\circ} \mathrm{C}$ for the reduction of nitroarenes to produce aniline. However, as mentioned above, the cost of the raw materials was high owing to the ligands being expensive.

In our previous work, we found that $\mathrm{N}$-doped $\mathrm{C}$ with a high surface area could be produced by pyrolysis of lignin at $800{ }^{\circ} \mathrm{C}$ in ammonia atmosphere [57], and N-doped C-cooperated metal catalysts such as Mo-N-C [58] and Co-N-C [59] could be obtained by co-pyrolysis of biomass and simple metal salts. However, the presences of different metals may exhibit different effects on catalyst preparation, depending on, for example, the form of the metal and the change in the $\mathrm{C}$ material. In this work, magnetic Fe-N-C catalysts were prepared by co-pyrolysis of the widely available cellulose and $\mathrm{FeCl}_{3}$ under ammonia atmosphere. The catalysts synthesized at different temperatures were characterized and tested for the hydrogenation of nitrobenzene. Combined with the results of catalyst characterization and comparative tests, the factors affecting the catalytic activity were proposed. The influence of the reaction conditions was determined and the stability of the catalyst was investigated.

\section{Experimental}

\subsection{Reagents}

$\alpha$-Cellulose (particle size $=50 \mu \mathrm{m}$ ) and cyclohexane were purchased from Aladdin Chemistry Co., Ltd. $\mathrm{FeCl}_{3}$, nitrobenzene, aniline, ethanol, and tetrahydrofuran were purchased from Sinopharm Chemical Reagent Co., Ltd.

\subsection{Catalyst preparation}

All the Fe-N-C catalysts were prepared via in situ co-pyrolysis method. The catalysts were labeled as Fe-N-C- $T$ (where $T$ is the pyrolysis temperature, which can be 500,600, 700 , or $800{ }^{\circ} \mathrm{C}$ ). The preparation process of $\mathrm{Fe}-\mathrm{N}-\mathrm{C}-700$, for example, is as follows: $5 \mathrm{~g}$ of $\alpha$-cellulose and $1.16 \mathrm{~g}$ of $\mathrm{FeCl}_{3}$ were uniformly mixed by grinding. The powder was transferred into a feed tube and purged with $\mathrm{NH}_{3}$ for $30 \mathrm{~min}$, before it was added into a quartz tube slowly heated by a furnace at $300{ }^{\circ} \mathrm{C}$ under $\mathrm{NH}_{3}$ flow. After feeding, the temperature was held at $300{ }^{\circ} \mathrm{C}$ for $30 \mathrm{~min}$ and then raised at the rate of $1{ }^{\circ} \mathrm{C} / \mathrm{min}$ to a certain pyrolysis temperature, which was $700{ }^{\circ} \mathrm{C}$. The temperature was then kept at $700{ }^{\circ} \mathrm{C}$ for $2 \mathrm{~h}$, before cooling to room temperature in $\mathrm{NH}_{3}$ flow. The powder was then purged with $\mathrm{N}_{2}$ for $2 \mathrm{~h}$.

The procedure for preparing $\mathrm{N}-\mathrm{C}-700$ was the same as that of Fe-N-C-700, but no $\mathrm{FeCl}_{3}$ was added to cellulose. The procedure for preparing Fe-C-700 was also the same as that of Fe-N-C-700, but $\mathrm{NH}_{3}$ was replaced by $\mathrm{N}_{2}$. The procedure for the preparation of $\mathrm{Fe} / \mathrm{N}-\mathrm{C}-700$ is as follows: $0.5 \mathrm{~g}$ of $\mathrm{N}-\mathrm{C}-700$ was added to a $100 \mathrm{~mL}$ round-bottom flask with $40 \mathrm{~g}$ of acetone and stirred at $45^{\circ} \mathrm{C}$. $0.3027 \mathrm{~g}$ of $\mathrm{FeCl}_{3}$ was dissolved in $10 \mathrm{~g}$ of acetone and then added to the above suspension, which could keep the Fe contents of the catalysts $\mathrm{Fe} / \mathrm{N}-\mathrm{C}-700$ and Fe-N-C-700 same. The mixture was stirred at $45{ }^{\circ} \mathrm{C}$ for $24 \mathrm{~h}$. The solvent was then removed by rotary evaporation and dried at $105{ }^{\circ} \mathrm{C}$ for $10 \mathrm{~h}$. After drying, the powder was reduced by $\mathrm{H}_{2}$ in a quartz tube furnace at $700{ }^{\circ} \mathrm{C}$ for $2 \mathrm{~h}$ at a heating rate of 1 ${ }^{\circ} \mathrm{C} / \mathrm{min}$. After cooling to room temperature, the catalyst was purged with $\mathrm{N}_{2}$ for $2 \mathrm{~h}$. After the preparation, all the catalysts were stored in a glovebox before use.

\subsection{Catalyst characterization}

The $\mathrm{N}_{2}$ adsorption-desorption isotherms were measured using a Micromeritics TriStar II system (TriStar II 3020 V1.03). The surface area was determined by the Brunauer-Emmett-Teller (BET) method. The average pore volume and pore size were measured by Barrett-Joyner-Halenda method. Powder X-ray diffraction (XRD) patterns were recorded on an X'pert (PANalytical) diffractometer using $\mathrm{Cu} K_{\alpha}$ radiation at 40 $\mathrm{kV}$ and $40 \mathrm{~mA}$; the $2 \theta$ range was $20^{\circ}-80^{\circ}$. The transmission electron microscopy (TEM) images were recorded by using a JEOL Model JEM-2010 LaB6 TEM system. High-resolution transmission electron microscopy (HRTEM) images were also obtained with the help of a JEOL-2100F system operating at $200 \mathrm{kV}$. X-ray photoelectron spectroscopy (XPS) was carried out with an X-ray photoelectron spectrometer (ESCALAB250). Elemental analysis was performed by using an Elementar vario EL cube. The combustion tube temperature was $950^{\circ} \mathrm{C}$, and the reducing tube temperature $550{ }^{\circ} \mathrm{C}$. Atomic absorption spec- 
troscopy (AAS) was performed on a PerkinElmer Corporation Analyst 800 instrument. The sample handling process was as follows: $20 \mathrm{mg}$ of the catalyst was added into a $25 \mathrm{~mL}$ round-bottom flask with $10 \mathrm{~mL}$ of aqua regia and stirred at 80 ${ }^{\circ} \mathrm{C}$ for $36 \mathrm{~h}$. The mixture was then diluted to $100 \mathrm{~mL}$ in a volumetric flask.

\subsection{Catalyst testing}

All reactions were performed in a $25 \mathrm{~mL}$ Parr reactor. In a typical experiment, $0.5 \mathrm{mmol}$ of nitrobenzene, $50 \mathrm{mg}$ of the catalyst, and solvent ( $5 \mathrm{~mL}$ each of water and tetrahydrofuran) were added into the reactor. After purging several times with hydrogen, the reactor was pressured with $5 \mathrm{MPa} \mathrm{H}_{2}$ at ambient temperature. The reactions were conducted at a certain temperature for a certain time with magnetic stirring. After the reactions, the products were separated from the catalyst by an external magnet and then diluted with ethanol, identified via gas chromatography-mass spectrometry (GC-MS; Agilent, Model 5975C), and quantified with a gas chromatograph (Kexiao, Model GC99) equipped with a HP-INNOWAX capillary column $(30 \mathrm{~m} \times 0.250 \mathrm{~mm} \times 0.25 \mu \mathrm{m})$. The GC detection conditions were as follows: $\mathrm{N}_{2}$ was the carrier gas; injection port temperature $=280{ }^{\circ} \mathrm{C}$; detector (FID) temperature $=280{ }^{\circ} \mathrm{C}$; column temperature $=50{ }^{\circ} \mathrm{C}$; and heating to $250{ }^{\circ} \mathrm{C}$ at the rate of 10 ${ }^{\circ} \mathrm{C} / \mathrm{min}$. Cyclohexane was used as the internal standard to quantify the products.

\subsection{Catalyst recycling}

After the reaction, the catalyst was separated from the solution with the help of an external magnet and washed three times with tetrahydrofuran. Afterwards, the catalyst was directly reused in the next run.

\section{Results and discussion}

In order to explore the characteristics of the catalysts, a series of tests were carried out, as the results show in Table 1 and S1. As the pyrolysis temperature increased, the surface areas of the catalysts first increased and then decreased, and the highest surface area was obtained when the catalyst was prepared at $700{ }^{\circ} \mathrm{C}$. As for the pore volume, as the temperature increased from 600 to $800{ }^{\circ} \mathrm{C}$, the pore volume increased significantly, indicating that a high temperature is favorable for the formation of pores, which is one of the main reasons for the increase in the surface area. The contents of different elements are also shown in Table 1 . Consistent with our previous re- search, the $\mathrm{N}, \mathrm{H}$, and $\mathrm{O}$ contents gradually decreased with the increase in the pyrolysis temperature, whereas the $\mathrm{C}$ and $\mathrm{Fe}$ contents revealed opposite trends. When the pyrolysis temperature was raised from 500 to $800{ }^{\circ} \mathrm{C}$, the Fe content increased from 12.91 to $22.22 \mathrm{wt} \%$.

The morphologies of the catalysts were characterized by TEM. As revealed in Fig. 1, when the pyrolysis temperature was $500{ }^{\circ} \mathrm{C}$, only sheet-like $\mathrm{N}$-doped $\mathrm{C}$, formed by the carbonization of cellulose in ammonia atmosphere, was found, and no significant metal particles were observed. When the temperature was increased to $600{ }^{\circ} \mathrm{C}$, the metal particles, with the average size of $5.1 \mathrm{~nm}$, were well dispersed on the $\mathrm{C}$ material. Upon further increasing the temperature to $700{ }^{\circ} \mathrm{C}$, larger metal particles, with an average size of $9.1 \mathrm{~nm}$, were observed. Moreover, the morphology of the $\mathrm{C}$ material transformed into curled lamellar. These changes are better reflected in Fe-N-C-800, and more pronounced metal agglomeration and curled $\mathrm{C}$ materials were observed. To explore this change, XRD was carried out. As shown in Fig. 2, no diffraction peaks were detected when the catalyst was prepared at $500{ }^{\circ} \mathrm{C}$, which indicated that the $\mathrm{C}$ material was amorphous and that the metal particles were well dispersed on the $C$ material. This is consistent with the TEM results in that no obvious particles were found (Fig. 1(a)). For Fe-N-C-600, the diffraction peaks observed at $37.7^{\circ}, 40.9^{\circ}$, $43.0^{\circ}$, and $56.7^{\circ}$ were attributed to the (021), (200), (121), and (221) planes, respectively, of orthorhombic $\mathrm{Fe}_{2} \mathrm{~N}$. However, upon further increasing the temperature to $700{ }^{\circ} \mathrm{C}$, the peaks of $\mathrm{Fe}_{2} \mathrm{~N}$ disappeared and new diffraction peaks emerged. All the peaks within the range $35^{\circ}-60^{\circ}$ were attributed to the $\mathrm{Fe}_{3} \mathrm{C}$ phase, which indicated that $\mathrm{Fe}_{2} \mathrm{~N}$ could transform to $\mathrm{Fe}_{3} \mathrm{C}$ when the pyrolysis temperature reached $700{ }^{\circ} \mathrm{C}$. In addition, a new peak at $26^{\circ}$ was observed, which should correspond to the diffraction peak of graphitic C. It was demonstrated that when the temperature rose to $700{ }^{\circ} \mathrm{C}$, the formed $\mathrm{C}$ material began to graphitize. When the temperature further rose to $800{ }^{\circ} \mathrm{C}$, this peak became sharper, which indicated that the material was further graphitized. Therefore, the morphological change observed in the TEM image of the $\mathrm{C}$ material should be attributed to the graphitization of the $\mathrm{C}$ support. HRTEM characterization of the Fe-N-C-700 catalyst was carried out to further explore its structure. As shown in Fig. 1(e), well-resolved fringes with an interplanar spacing of $0.201 \mathrm{~nm}$ were observed; this spacing was close to that of the (031) planes of $\mathrm{Fe}_{3} \mathrm{C}$. Moreover, a graphitic C layer of thickness about $5.2 \mathrm{~nm}$ wrapped around the particles. These are consistent with the results of XRD analysis.

In order to confirm the valence states of Fe and N, XPS was used to analyze the catalysts. Deconvolution of the $\mathrm{N} 1 s$ regions by peak fitting for Fe-N-C catalysts is shown in Fig. 3. Five dis-

Table 1

Characteristics of Fe-N-C-T catalysts.

\begin{tabular}{|c|c|c|c|c|c|c|c|c|}
\hline \multirow{2}{*}{ Sample } & \multirow{2}{*}{$\begin{array}{c}A_{\mathrm{BET}} \\
\left(\mathrm{m}^{2} / \mathrm{g}\right)\end{array}$} & \multirow{2}{*}{$\begin{array}{c}\text { Pore volume } \\
\left(\mathrm{cm}^{3} / \mathrm{g}\right)\end{array}$} & \multirow{2}{*}{$\begin{array}{c}\text { Pore size } \\
\text { (nm) }\end{array}$} & \multicolumn{5}{|c|}{ Content (\%) } \\
\hline & & & & $\mathrm{Ca}^{\mathrm{a}}$ & $\mathrm{Na}^{\mathrm{a}}$ & $\mathrm{H}^{\mathrm{a}}$ & 0 & $\mathrm{Fe}^{\mathrm{b}}$ \\
\hline Fe-N-C-500 & 53.3 & 0.005 & 7.5 & 52.94 & 19.80 & 3.02 & 11.33 & 12.91 \\
\hline Fe-N-C-600 & 79.7 & 0.003 & 4.6 & 51.69 & 17.54 & 2.20 & 14.3 & 14.27 \\
\hline Fe-N-C-700 & 298 & 0.089 & 7.4 & 60.99 & 6.90 & 1.97 & 12.89 & 17.25 \\
\hline Fe-N-C-800 & 238 & 0.305 & 10.0 & 72.09 & 2.08 & 0.61 & 3.00 & 22.22 \\
\hline
\end{tabular}

a Determined by CHN analyses. ${ }^{b}$ Determined by ICP-OES. 


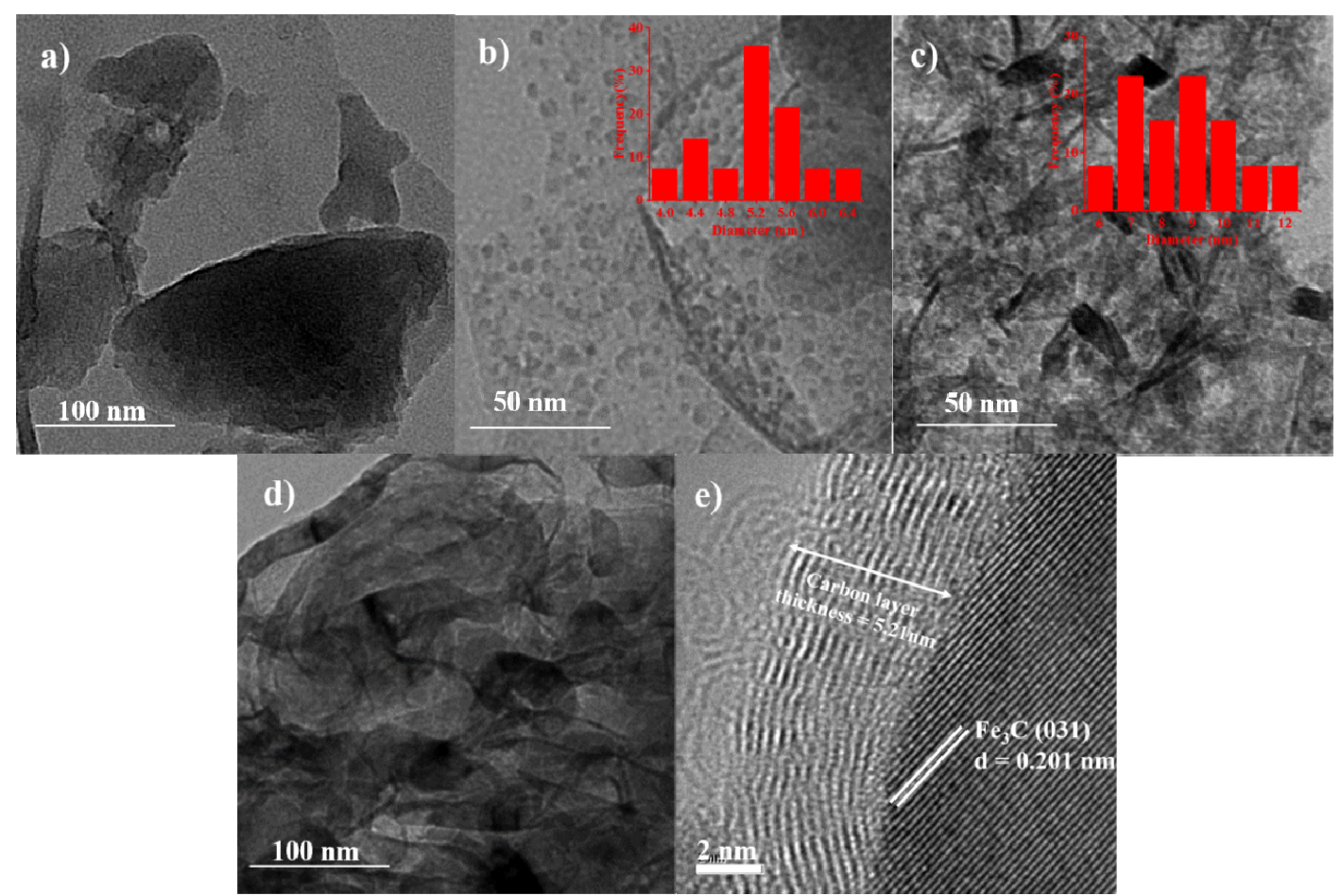

Fig. 1. TEM images of Fe-N-C-500 (a), Fe-N-C-600 (b), Fe-N-C-700 (c), and Fe-N-C-800 (d); HRTEM image of Fe-N-C-700 (e).

tinct peaks were observed in the $\mathrm{N} 1 s$ spectra of Fe-N-C. The peaks at the binding energies of 398.6, 399.7, 400.5, 401.2, and 402-405 eV can be attributed to pyridinic N, bridge N, pyrrolic $\mathrm{N}$, graphitic $\mathrm{N}$, and oxidized $\mathrm{N}$, respectively, and their specific contents are displayed in Table S2 [60,61]. As for graphitic $\mathrm{N}$, its content increased as the temperature increased. The content of graphitic $\mathrm{N}$ was $13.20 \%$ in Fe-N-C-700 and $26.05 \%$ in Fe-N-C-800. For Fe-N-C-500, a peak at $399.7 \mathrm{eV}$ can be observed, which is assigned to bridge $\mathrm{N}$, which refers to tertiary $\mathrm{N}$ bonded to $\mathrm{C}$ atoms in the form of $\mathrm{N}-(\mathrm{C})_{3}$ or $\mathrm{H}-\mathrm{N}-(\mathrm{C})_{2}$ [62]. Upon further increasing the pyrolysis temperature, this peak dis-

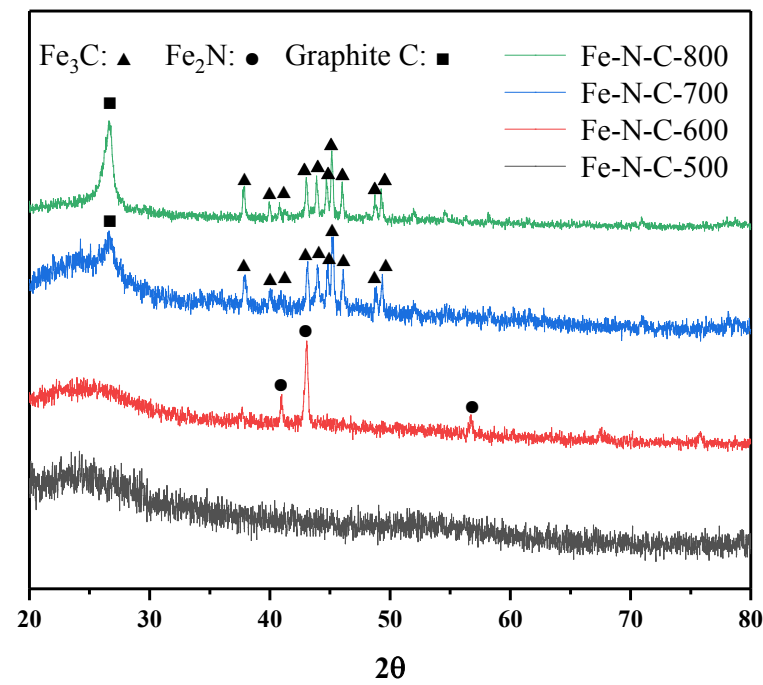

Fig. 2. XRD patterns of the Fe-N-C catalysts prepared at different pyrolysis temperatures. appeared. The content of pyridinic $\mathrm{N}$ decreased with the increase in the pyrolysis temperature, whereas the content of pyrrolic $\mathrm{N}$ first increased and then decreased. These results revealed changes in the $\mathrm{N}$-incorporated form during the catalyst preparation. The presence of these types of $\mathrm{N}$ not only resulted in the formation of surface defects on the catalyst, but also contributed to the reduction and dispersion of the metal precursor as an electron-rich active site, and played an important role in enhancing the interaction between the active component and the carrier [63]. The Fe $2 p$ XPS patterns of the Fe-N-C catalysts are exhibited in Fig. 3(b). Only $\mathrm{Fe}^{2+}$ and $\mathrm{Fe}^{3+}$ are observed, but no $\mathrm{Fe}_{2} \mathrm{~N}$ or $\mathrm{Fe}_{3} \mathrm{C}$ is found, although they were detected in XRD. This should be attributed to the fact that the Fe species on the particle surface were easily oxidized when the catalysts were exposed to air.

The activities of the catalysts were evaluated for the hydrogenation of nitrobenzene. As shown in Table 2, the catalysts with different pyrolysis temperatures revealed significant differences in the activities. As the pyrolysis temperature increased, the catalytic activity first increased and then decreased. For Fe-N-C-500, the nitrobenzene conversion was $28.3 \%$ and the yield of aniline was $27.9 \%$. The catalytic activity of Fe-N-C-600 increased, and, when the pyrolysis temperature increased to $700{ }^{\circ} \mathrm{C}$, the conversion of nitrobenzene was $99.9 \%$ and the yield of aniline was $98.0 \%$. When Fe-N-C-800 was used as the catalyst, $94 \%$ of aniline was obtained, which suggested a slight decrease in the catalytic activity. Besides aniline, the loss of balance $\mathrm{C}$ was due to some intermediates such as nitrosobenzene, aromatic hydroxylamine, and azo compounds. As the $\mathrm{H}_{2}$ pressure dropped from 5 to $3 \mathrm{MPa}$, the conversion decreased in the cases of both Fe-N-C-700 and Fe-N-C-800, 

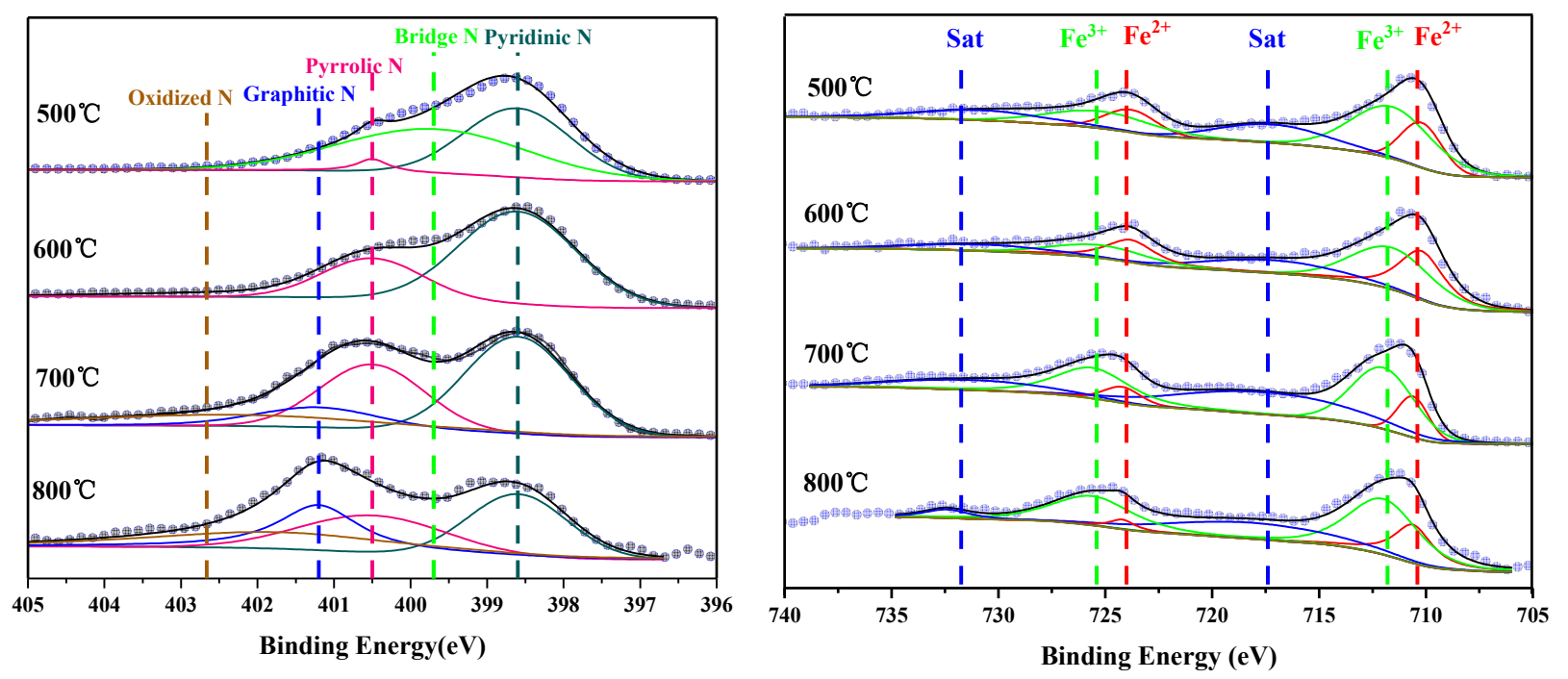

Fig. 3. $\mathrm{N} 1 s$ and Fe $2 p$ XPS patterns of Fe-N-C catalysts prepared at different pyrolysis temperatures.

though the reduction was higher in the case of the latter, which further indicated that Fe-N-C-700 showed the highest catalytic activity. In order to exclude the difference in the activities caused by the difference in the Fe contents of the catalysts, we adjusted the amount of the $\mathrm{Fe}$ precursor such that the Fe-N-C-T- $m$ (where $m$ is the mass in grams of the initial feed of $\mathrm{FeCl}_{3}$ ) catalysts prepared at different pyrolysis temperatures exhibited similar Fe contents. The activities of these catalysts were compared and the results are shown in Table S3. Fe-N-C-700 still showed the highest catalytic activity. The XPS patterns and the contents of the different types of $\mathrm{N}$ of the catalysts are displayed in Fig. S1 and Table S4, respectively.

According to the results of TEM, the metal particles of Fe-N-C-600 better dispersed on the N-doped C carrier than those of Fe-N-C-700. However, Fe-N-C-700 revealed the better catalytic activity. Based on the XRD analysis, the catalyst prepared at $600{ }^{\circ} \mathrm{C}$ was mainly $\mathrm{Fe}_{2} \mathrm{~N}$, whereas the catalyst obtained at $700{ }^{\circ} \mathrm{C}$ was mainly $\mathrm{Fe}_{3} \mathrm{C}$. The change in the composition of the catalyst may be the main reason for the change in the catalytic activity. On the other hand, the increase in the pyrolysis temperature caused a change in the support. Based on the XRD and XPS analyses, when the temperature reached $700{ }^{\circ} \mathrm{C}$, graphitized $\mathrm{N}$-doped $\mathrm{C}$ was formed, which may improve the activity of the catalyst. According to previous studies, the doping of graphitic $\mathrm{N}$ into graphene structure, especially when two graphite $\mathrm{N}$ atoms were doped into the same hexagon, can form a non-uniform electron distribution, which enhances the catalytic activity of the $C$ surface significantly [64]. The performance of Fe-N-C-800 further confirms this finding. When the catalyst was prepared at $800{ }^{\circ} \mathrm{C}$, the metal particles significantly agglomerated, but, at this time, the activity of the catalyst only changed slightly (Table 2, entries 3 and 4). XRD and XPS showed that the Fe species in the two catalysts did not change significantly, but the content of graphitized $\mathrm{N}$-doped $\mathrm{C}$ in Fe-N-C-800 was higher. This illustrates the effect of graphitized $\mathrm{N}$-doped $\mathrm{C}$ on catalytic activity. In addition, it should be emphasized that we cannot rule out other forms of Fe species that were not detected but which display activities towards the reaction, because the structure of the catalyst is very complicated. In addition to graphite $\mathrm{N}$, other forms of $\mathrm{N}$ such as pyridine or pyrrole $\mathrm{N}$ may also promote the reaction. Previous studies reported that pyridinic $\mathrm{N}$ mainly appeared at the edge of the material as a Lewis base site, which can render adjacent $\mathrm{C}$ atom sites as active centers. Furthermore, owing to its electron donating property, the pyridinic $\mathrm{N}$ has been considered as a binding site of transition metals and an active center in the catalyst. In this work, these $\mathrm{N}$ may also combine with Fe species $\left(\mathrm{Fe}^{2+}\right.$ or $\left.\mathrm{Fe}^{3+}\right)$ to catalyze the reaction, although they may not be the main active centers.

In order to further demonstrate the effects of $\mathrm{Fe}$ and $\mathrm{N}$,

Table 2

Hydrogenation of nitrobenzene over Fe-N-C catalysts.

\begin{tabular}{|c|c|c|c|c|c|c|}
\hline Entry & Sample & Reaction temperature $\left({ }^{\circ} \mathrm{C}\right)$ & $\mathrm{H}_{2}$ pressure $(\mathrm{MPa})$ & Time (h) & Conversion (\%) & Yield (\%) \\
\hline 1 & Fe-N-C-500 & 120 & 5 & 12 & 28.3 & 27.9 \\
\hline 2 & Fe-N-C-600 & 120 & 5 & 12 & 75.5 & 69.0 \\
\hline 3 & Fe-N-C-700 & 120 & 5 & 12 & 99.9 & 98.0 \\
\hline 4 & Fe-N-C-800 & 120 & 5 & 12 & 99.9 & 94.1 \\
\hline 5 & Fe-N-C-700 & 120 & 3 & 12 & 90.6 & 84.2 \\
\hline 6 & Fe-N-C-800 & 120 & 3 & 12 & 68.3 & 64.0 \\
\hline 7 & $\mathrm{~N}-\mathrm{C}-700$ & 120 & 5 & 12 & 3.3 & Trace \\
\hline 8 & Fe-C-700 & 120 & 5 & 12 & 21.7 & 20.9 \\
\hline 9 & $\mathrm{Fe} / \mathrm{N}-\mathrm{C}-700$ & 120 & 5 & 12 & 42.5 & 40.0 \\
\hline
\end{tabular}

Reaction conditions: $0.5 \mathrm{mmol}$ of nitrobenzene, $50 \mathrm{mg}$ of catalyst, $5 \mathrm{~mL}$ of water, and $5 \mathrm{~mL}$ of tetrahydrofuran. 

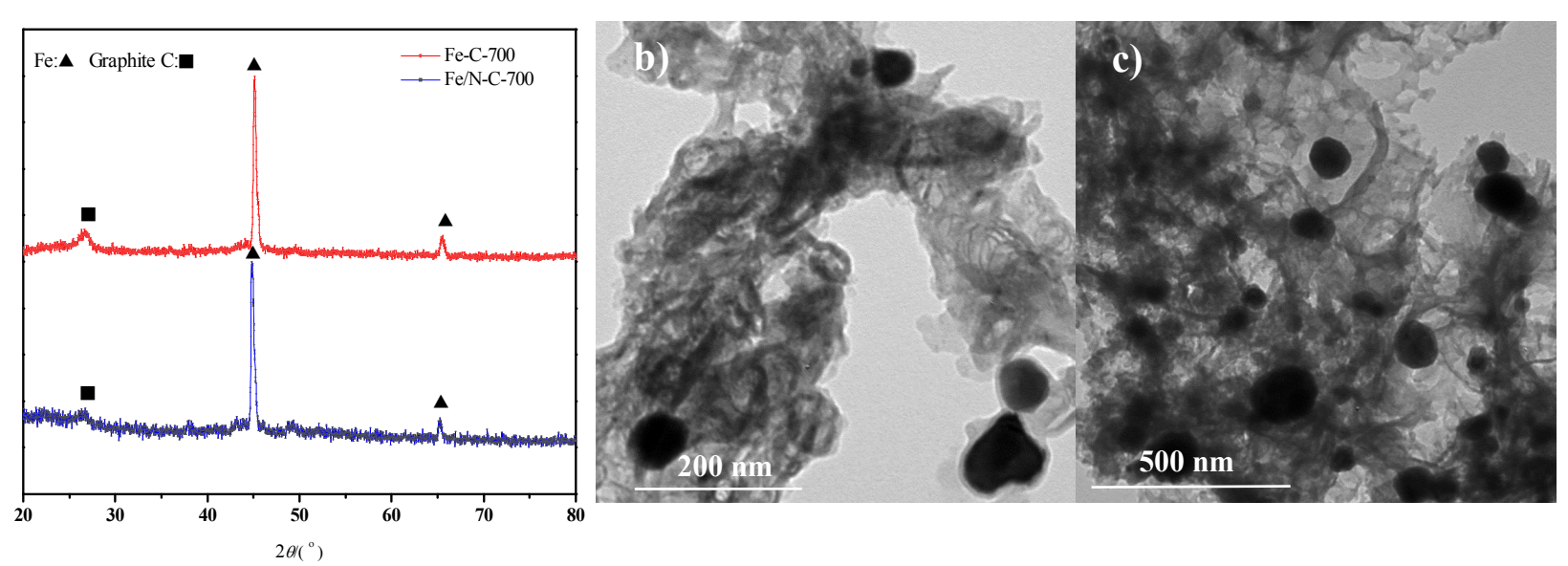

Fig. 4. (a) XRD patterns of Fe-C-700 and Fe/N-C-700 catalysts; TEM images of Fe-C-700 (b) and Fe/N-C-700 (c).

comparative tests were carried out. As shown in Table 2 (entries 7 and 8), almost no aniline was produced when no Fe was present in the catalyst, which indicated that the Fe species were the active centers for the catalysis of the hydrogenation of nitrobenzene. However, when Fe-C-700, which was obtained by pyrolysis under $\mathrm{N}_{2}$ atmosphere, was used as the catalyst, only $20.9 \%$ of aniline was obtained under the same reaction conditions. XRD analysis (Fig. 4(a)) showed that the Fe species mainly existed in the form of metallic $\mathrm{Fe}$, which could have come from the Fe precursor reduced by the reducing species produced during the pyrolysis of cellulose, such as $\mathrm{CO}, \mathrm{H}_{2}$, and $\mathrm{C}_{x} \mathrm{H}_{y}$ [65]. This indicated that without the incorporation of $\mathrm{N}$, the activity of the catalyst was very low. In addition, the TEM images (Fig. 4(b) and (c)) showed that the metal particles on Fe-C-700 were significantly larger than those on Fe-N-C-700. This indicated that the presence of $\mathrm{N}$ was conducive to the dispersion of metal particles, which is consistent with previous studies. The well-dispersed metal particles also enhanced the activity of the catalyst. The N-C-700 supported metallic Fe catalyst (Fe/N-C-700) was also prepared and $45 \%$ aniline was obtained. This result further demonstrated that the presence of $\mathrm{N}$ in the support could improve the activity of the catalyst.

We also studied the effect of reaction temperature (Fig. 5).

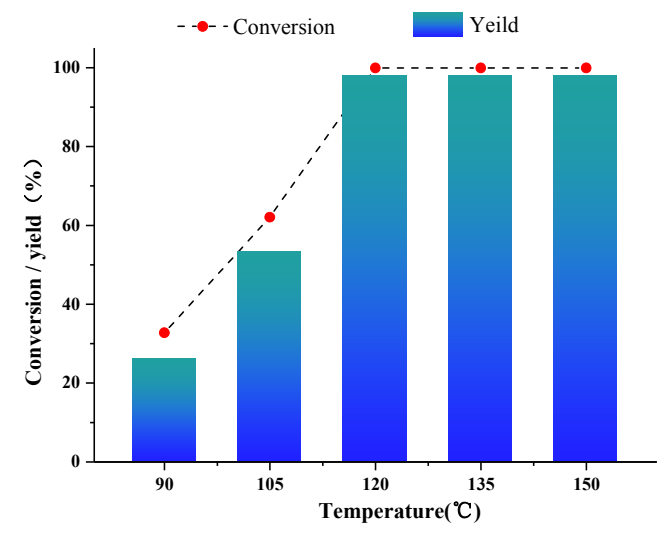

Fig. 5. Effect of reaction temperature. Reaction conditions: $0.5 \mathrm{mmol}$ of nitrobenzene, $5 \mathrm{~mL}$ of water, $5 \mathrm{~mL}$ of tetrahydrofuran, $50 \mathrm{mg}$ of Fe-N-C-700, $5 \mathrm{MPa} \mathrm{H}_{2}, 12$ h.
When the temperature was low, the reaction proceeded slowly and not much of the substance was involved in the reaction. On the other hand, when the temperature was above $120^{\circ} \mathrm{C}$, nitrobenzene was completely converted, and the yield of aniline reached $98 \%$. The stability of Fe-N-C-700 catalyst was investigated for the conversion of nitrobenzene to aniline, and the results are shown in Fig. 6. After five runs, the yield of aniline barely changed, which indicated excellent recyclability of the catalyst.

A kinetic study was also carried out, and the results are displayed in Fig. 7. According to previous reports, the activation energy of the nitrobenzene hydrogenation reaction is 91.5 $\mathrm{kJ} / \mathrm{mol}$ [66]. On the other hand, in our work, the apparent activation energy was reduced to $31.53 \mathrm{~kJ} / \mathrm{mol}$ when $\mathrm{Fe}-\mathrm{N}-\mathrm{C}-700$ was used as the catalyst, which suggested that the Fe-N-C-700 catalyst can effectively reduce the activation energy of the reaction.

\section{Conclusions}

A simple method with cellulose as the C source, ferric chloride as the metal source, and ammonia as the $\mathrm{N}$ source has been proposed for the preparation of Fe-N-C catalysts. A series of

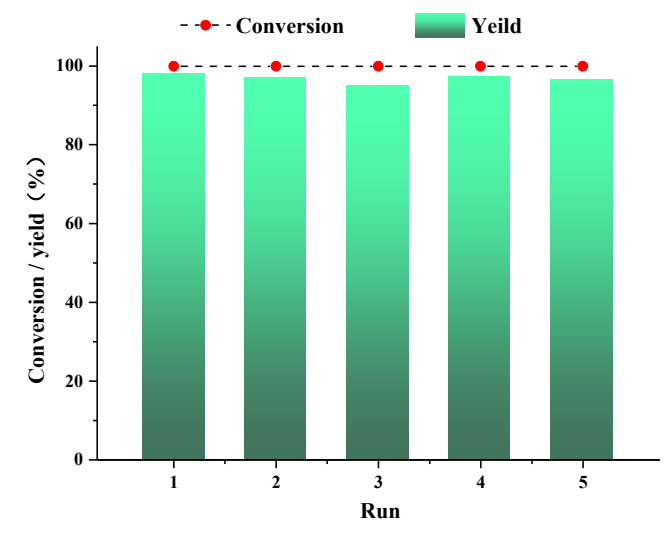

Fig. 6. Recycling results of the catalyst. Reaction conditions: $0.5 \mathrm{mmol}$ of nitrobenzene, $5 \mathrm{~mL}$ of water, $5 \mathrm{~mL}$ of tetrahydrofuran, $50 \mathrm{mg}$ of Fe-N-C-700, $5 \mathrm{MPa} \mathrm{H}_{2}, 120^{\circ} \mathrm{C}, 12 \mathrm{~h}$. 

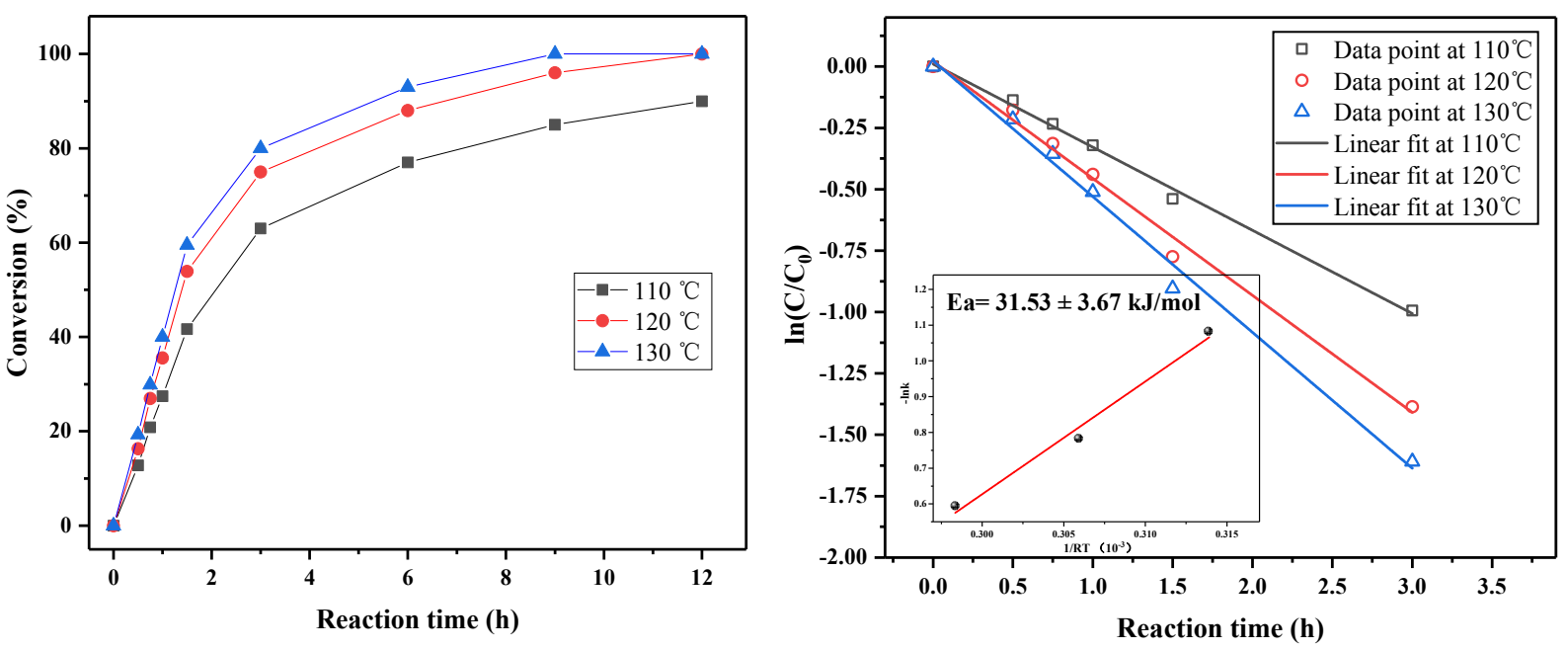

Fig. 7. Kinetic calculations based on reaction rate.

catalysts were prepared at different pyrolysis temperatures and characterized. Through BET, TEM, HRTEM, XRD, XPS, AAS, and elemental analysis, it was found that the pyrolysis temperature exhibits a great influence on the morphology, elemental content, and composition of the catalyst. Using nitrobenzene as a model compound, the pyrolysis temperature displays a significant effect on the catalytic activity towards hydrogenation of nitrobenzene. Among these catalysts, Fe-N-C-700 exhibited excellent activity. The conversion of nitrobenzene was $99.9 \%$ and the yield of aniline $98.0 \%$ under $5 \mathrm{MPa} \mathrm{H}_{2}$ at $120{ }^{\circ} \mathrm{C}$ after $12 \mathrm{~h}$. Combined with the results of catalyst characterization and comparison experiments, the transformation of the Fe species and the generation of $\mathrm{N}$-doped $\mathrm{C}$, especially graphitized $\mathrm{N}$-doped $\mathrm{C}$, in the catalyst may be the main factors affecting the activity of the catalyst. A kinetic study was carried out and the apparent activation energy obtained was $31.53 \mathrm{~kJ} / \mathrm{mol}$. The stability of the catalyst was also investigated and no significant decrease in the activity was observed after 5 runs.

\section{Acknowledgments}

We gratefully acknowledge the financial supports from NSFC (51876200 and 21572213) and DNL Cooperation Fund, CAS (DNL180301).

\section{References}

[1] A. Corma, P. Serna, Science, 2006, 5785, 332-334.

[2] F. Meemken, A. Baiker, Chem. Rev., 2017, 117, 11522-11569.

[3] W. Zang, G. Li, L. Wang, X. Zhang, Catal. Sci. Technol., 2015, 5, 2532-2553.

[4] F. Yao, Y. Huo, Y. Ma, Chin. J. Chem. Phys., 2017, 30, 559-565.

[5] X. Tong, F. Yang, J. Ren, J. Cai, N. Lu, X. Jiang, Chin. J. Inorg. Chem., 2018, 34, 129-134.

[6] J. G. Chen, Chem. Rev., 1996, 96, 1477-1498.

[7] P. D. Tran, A. Morozan, S. Archambault, J. Heidkamp, P. Chenevier, H. Dau, M. Fontecave, A. Martinent, B. Jousselme, V. Artero, Chem. Sci., 2015, 6, 2050-2053.

[8] Y. Ren, H. Wei, G. Yin, L. Zhang, A. Wang, T. Zhang, Chem.Commun.,
2017, 53, 1969-1972.

[9] J. Sun, Q. Cai, Y. Wan, S. Wan, L. Wang, J. Lin, D. Mei, Y. Wang, ACS Catal., 2016, 6, 5771-5785.

[10] S. Enthaler, K. Junge, M. Beller, Angew. Chem. Int. Ed., 2008, 47, 3317-3321.

[11] R. Schlögl, Angew. Chem. Int. Ed., 2003, 42, 2004-2008.

[12] M. A. Vannice, J. Catal., 1977, 50, 228-236.

[13] F. Liu, K. Asakura, H. He, W. Shan, X. Shi, C. Zhang, Appl. Catal. B, 2011, 103, 369-377.

[14] L. Lin, Z. K. Yang, Y. F. Jiang, A. W. Xu, ACS Catal., 2016, 6, 4449-4454.

[15] Y.-C. Wang, Y.-J. Lai, L. Song, Z.-Y. Zhou, J.-G. Liu, Q. Wang, X.-D. Yang, C. Chen, W. Shi, Y.-P. Zheng, M. Rauf, S.-G. Sun, Angew. Chem., Int. Ed., 2015, 54, 9907 - 9910.

[16] G. Wu, K. L. More, C. M. Johnston, P. Zelenay, Science, 2011, 332, 443-447.

[17] Y. Zhao, K. Watanabe, K. Hashimoto, J. Am. Chem. Soc., 2012, 134, 19528-19531.

[18] M. Lefèvre, E. Proietti, F. Jaouen, J.-P. Dodelet, Science, 2009, 324, 71-74.

[19] T. N. Huan, N. Ranjbar, G. Rousse, M. Sougrati, A. Zitolo, V. Mougel, F. Jaouen, M. Fontecave, ACS Catal., 2017, 7, 1520-1525.

[20] M. Zeng, Y. Liu, F. Zhao, K. Nie, N. Han, X. Wang, W. Huang, X. Song, J. Zhong, Y. Li, Adv. Funct. Mater., 2016, 26, 4397-4404.

[21] H. Jin, J. Wang, D. Su, Z. Wei, Z. Pang, Y. Wang, J. Am. Chem. Soc., 2015, 137, 2688-2694.

[22] H. W. Liang, S. Bruller, R. Dong, J. Zhang, X. Feng, K. Mullen, Nat. Commun., 2015, 6, 7992.

[23] H. Fei, J. Dong, M. J. Arellano-Jimenez, G. Ye, N. D. Kim, E. L. G. Samuel, Z. Peng, Z. Zhu, F. Qin, J. Bao, M. J. Yacaman, P. M. Ajayan, D. Chen, J. M. Tour, Nat. Commun., 2015, 6, 8668.

[24] Y. L. Wang, M. J. Wang, J. Li, Z. D. Wei, Chin. Chem. Lett., 2019, 77, 84-89.

[25] R. V. Jagadeesh, A. E., Surkus, H. Junge, M. M. Pohl, J. Radnik, J. Rabeah, H. Huan, V. Schunemann, A. Bruckner, M. Beller, Science, 2013, 342, 1073-1076.

[26] R. V. Jagadeesh, T. Stemmler, A.-E. Surkus, M. Bauer, M.-M Pohl, J. Radnik, K. Junge, H. Junge, A. Brückner, M. Beller, Nat. Protoc., 2015, 10, 916-926.

[27] F. A. Westerhaus, R. V. Jagadeesh, G. Wienhofer, M. M. Pohl, J. Radnik, A. E. Surkus, J. Rabeah, K. Junge, H. Junge, M. Nielsen, A. Bruckner, M. Beller, Nat. Chem., 2013, 5, 537-543. 
[28] D. Deng, X. Chen, L. Yu, X. Wu, Q. Liu, Y. Liu, H. Yang, H. Tian, Y. Hu, P. Du, R. Si, J. Wang, X. Cui, H. Li, J. Xiao, T. Xu, J. Deng, F. Yang, P. N. Duchesne, P. Zhang, J. Zhou, L. Sun, J. Li, X. Pan, X. Bao, Sci. Adv., 2015, 1, e1500462/1-e1500462/9.

[29] L. Zhang, A. Wang, W. Wang, Y. Huang, X. Liu, S. Miao, J. Liu, T. Zhang, ACS Catal., 2015, 5, 6563-6572.

[30] W. Liu, L. Zhang, X. Liu, X. Liu, X. Yang, S. Miao W. Wang, A. Wang, T. Zhang, J. Am. Chem. Soc., 2017, 139, 10790-10798.

[31] J. Li, J. Liu, H. Zhou, Y. Fu, ChemSusChem, 2016, 9, 1339-1347.

[32] J. Li, J. Liu, H. Liu, G. Xu, J. Zhang, J. Liu, G. Zhou, Q. Li, Z. Xu, Y. Fu, ChemSusChem, 2017, 10, 1436-1447.

[33] W. Niu, L. Li, X. Liu, N. Wang, J. Liu, W. Zhou, Z. Tang, S. Chen, J. Am. Chem. Soc., 2015, 137, 5555-5562.

[34] F.-L. Meng, Z.-L. Wang, H.-X. Zhong, J. Wang, J.-M. Yan, X.-B. Zhang, Adv. Mater., 2016, 28, 7948-7955.

[35] E. Negro, A. H. A. M. Videla, V. Baglio, A. S. Aricò, S. Specchia, G. J. M. Kopera, Appl. Catal. B, 2015, 166, 75-83.

[36] S. Yasuda, A. Furuya, Y. Uchibori, J. Kim, K. Murakoshi, Adv. Funct. Mater., 2016, 26, 738-744.

[37] Z. Wang, D. Xu, H. Zhong, J. Wang, F. L. Meng, X. B. Zhang, Sci. Adv., 2015, 1, e1400035/1-e1400035/9.

[38] W. Zhong, J. Chen, P. Zhang, L. Deng, L. Yao, X. Ren, Y. Li, H. Mi, L. Sun, J. Mater. Chem. A, 2017, 5, 16605-16610.

[39] X. Wang, B. Wang, J. Zhong, F. Zhao, N. Han, W. Huang, M. Zeng, J. Fan, Y. Li, Nano Res., 2016, 9, 1497-1506.

[40] A. H. A. Monteverde Videla, S. Ban, S. Specchia, L. Zhang, J. Zhang, Carbon, 2014, 76, 386-400.

[41] R. J. Jasinski, Nature, 1964, 201, 1212-1213.

[42] L. Lin, Q. Zhu, A. Xu, J. Am. Chem. Soc., 2014, 136, 11027-11033.

[43] Z. Li, G. Li, L. Jiang, J. Li, G. Sun, C. Xia, F. Li, Angew. Chem. Int. Ed., 2015, 54, 1494-1498.

[44] H. A. Miller, M. Bellini, W. Oberhauser, Phys. Chem. Chem. Phys., 2016, 18, 33142-33151.

[45] H. T. Chung, J. H. Won, P. Zelenay, Nat. Commun., 2013, 4,
1922-1926.

[46] M. Rauf, R. Chen, Q. Wang, Carbon, 2017, 125, 605-613.

[47] H. U. Blaser, Science, 2006, 313, 312-313.

[48] C. Li, Z. Yu, K. Yao, S. Ji, J. Liang, J. Mol. Catal. A, 2005, 226, 101-105.

[49] R. Nie, J. Wang , L. Wang , Y. Qin , P. Chen , Z. Hou, Carbon, 2012, 50, 586-596.

[50] J. Liang, X. Zhang, L. Jing, H. Yang, Chin. J. Catal., 2017, 38, 1252-1260.

[51] E. A. Gelder, S. D. Jackson, C. M. Lok, Catal. Lett., 2002, 84, 205-208.

[52] B. Zuo, Y. Wang, Q. Wang, J. Zhang, N. Wu, L. Peng, L. Gui, X. Wang, R. Wang, D. Yu, J. Catal., 2004, 222, 493-498.

[53] A. Corma, P. Concepci, P. Serna, Angew. Chem. Int. Ed., 2007, 46, 7266-7269.

[54] Z. Peng, H. Wang, L. Zhou, Y. Wang, J. Gao, G. Liu, S. A. T. Redfern, X. Feng, S. Lu, B. Li, Z. Liu, J. Mater. Chem. A, 2019, 7, 6676-6685.

[55] Z. Peng, W. Li, Y. Miao, S. Chen, G. Liu, S. Liu, J. Gao, B. Li, Z. Liu, ACS Appl. Energy Mater., 2018, 1, 8, 4277-4284.

[56] R. V. Jagadeesh, A. E. Surkus, H. Junge, M. M. Pohl, J. Radnik, J. Rabeah, H. Huan, V. Schünemann, A. Brückner, M. Beller, Science, 2003, 342, 1073-1076.

[57] L. Xu, Q. Yao, Y. Zhang, Y. Fu, ACS Sustainable Chem. Eng., 2017, 5, 2960-2969.

[58] L. Xu, Z. Han, Y. Zhang, Y. Fu, RSC Adv., 2016, 6, 108217-108228.

[59] X. Liu, L. Xu, G. Xu, W. Jia, Y. Ma, Y. Zhang, ACS Catal., 2016, 6, 7611-7620.

[60] J. R. Pels, F. Kapteijn, J. A. Moulijn, Q. Zhu, K. M. Thomas, Carbon, 1995, 33, 1641-1653.

[61] D. Guo, R. Shibuya, C. Akida, S. Saji, T. Kondo, J. Nakamura, Science, 2016, 351, 31-365.

[62] J. Liu, T. Zhang, Z. Wang, G. Dawson, W. Chen, J. Mater. Chem., 2011, 21, 14398-14401.

[63] X. Xu, Y. Li, Y. Gong, P. Zhang, H. Li, Y. Wang, J. Am. Chem. Soc.,

\section{Graphical Abstract}

Chin. J. Catal., 2019, 40: 1557-1565 doi: S1872-2067(19)63416-9

\section{In situ synthesis of Fe-N-C catalysts from cellulose for hydrogenation of nitrobenzene to aniline}

Hao Wang, Xiaohao Liu, Guangyue Xu, Ziwei Guo, Ying Zhang*

University of Science and Technology of China; Dalian National Laboratory for Clean Energy

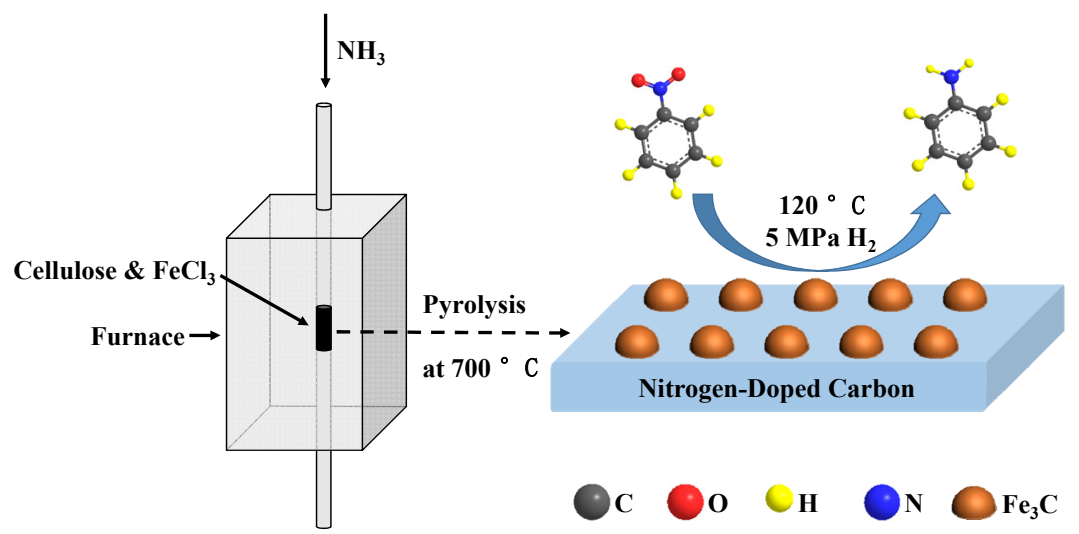

Nitrogen-doped carbon supported iron catalysts (Fe-N-C) were prepared via co-pyrolysis of the widely available cellulose and FeCl 3 under ammonia atmosphere. The catalyst showed good performance in hydrogenation of nitrobenzene. 
2012, 134, 16987-16990.

[64] M. Xiao, J. Zhu, L. Feng, C. Liu, W. Xing, Adv. Mater., 2015, 27, 2521-2527.
[65] W. J. Liu, K. Tian, H. Jiang, Green Chem., 2015, 17, 821-826.

[66] N. S. Abo-Ghander, J. R. Grace, S. S. E. H. Elnashaie, C. J. Lim, Chem. Eng. Sci., 2001, 63, 1817-1826.

\title{
纤维素原位合成Fe-N-C催化加氢硝基苯到苯胺
}

\author{
王 昊 ${ }^{\mathrm{a}, \uparrow}$, 刘小好 ${ }^{\mathrm{a}, \dagger}$, 许光月 ${ }^{\mathrm{a}}$, 郭子薇 $\mathrm{a}$, 张 颖, ${ }^{\mathrm{a}, \mathrm{b}, *}$ \\ $\mathrm{a}$ 中国科学技术大学化学与材料科学学院化学系, 安徽合肥 230026 \\ $\mathrm{b}$ 中国科学院洁净能源创新研究院, 辽宁大连 116023
}

\begin{abstract}
摘要: 贵金属被广泛用作各种反应的催化剂, 然而它们高昂的价格和有限的来源引起了人们对于开发非贵金属催化剂的浓 厚兴趣. 因此, 寻找一种丰富而有效的催化剂来代替贵金属已成为催化领域最重要的任务之一. 铁是地球上最丰富、最廉 价的过渡金属,同时铁基催化剂在合成氨, 费托合成和选择性还原氮氧化物等方面表现出优异的活性. 近年来, 廉价高效的 氮掺杂碳负载铁催化剂在各种典型的铂催化反应中表现出良好的催化性能, 尤其在催化加氢反应中的应用引起了研究人 员的关注. 本文通过在氨气氛围下共热解纤维素和氯化铁制备了一系列氮掺杂碳负载铁催化剂, 并通过元素分析、原子吸 收光谱、透射电子显微镜、X射线衍射和X射线光电子能谱等表征方法, 探索了催化剂的物理化学性质. 同时以硝基苯加氢 制备苯胺为模型反应, 探究了催化剂制备条件和反应条件对于催化剂活性的影响. 其中Fe-N-C-700 (通过在氨气氛围下 $700{ }^{\circ} \mathrm{C}$ 共热解纤维素和氯化铁制备)表现出最佳活性, 在 $5 \mathrm{MPa}$ 氢气和 $120{ }^{\circ} \mathrm{C}$ 的条件下反应 $12 \mathrm{~h}$, 硝基苯被完全转化, 苯胺的 收率可达 $98.0 \%$, 同时, 该催化剂还显示出良好的可再循环性, 5次运行后未见催化活性的显著降低.

BET和元素分析结果表明, 在热解温度为 $700{ }^{\circ} \mathrm{C}$ 的条件下制备的催化剂具有最高的比表面积, 并且随着热解温度的升 高, 催化剂中碳元素和铁元素的含量升高, 而氢、氮、氧元素的含量都随之下降. 根据TEM图像, 当热解温度升至 $600{ }^{\circ} \mathrm{C}$ 时, 在碳材料上可以观察到平均尺寸为 $5.1 \mathrm{~nm}$ 的金属颗粒, 分散性较好. 进一步将温度升至 $700{ }^{\circ} \mathrm{C}$, 观察到平均尺寸为 $9.1 \mathrm{~nm}$ 的 金属颗粒, 并且碳材料的形态结构转变为卷曲的层状. 在XRD分析中, $600{ }^{\circ} \mathrm{C}$ 时催化剂的衍射峰归因于正交晶系的 $\mathrm{Fe}_{2} \mathrm{~N}$, 随 着温度升至 $700{ }^{\circ} \mathrm{C}, \mathrm{Fe}_{2} \mathrm{~N}$ 相消失同时出现了 $\mathrm{Fe}_{3} \mathrm{C}$ 相. 在HRTEM的图谱中, 可以清晰地看到 $\mathrm{Fe}_{3} \mathrm{C}$ 相的(031)面的衍射条纹, 并 且在颗粒周围有约 $5.2 \mathrm{~nm}$ 厚的石墨碳层包裹. XPS结果表明, 当温度达到 $700{ }^{\circ} \mathrm{C}$ 时, 形成石墨化的氮掺杂碳, 提高了催化剂 活性. 结合催化剂表征结果和对比实验, 催化剂中铁物种的转变和氮掺杂碳尤其是石墨化的氮掺杂碳的生成可能是影响 催化剂活性的主要因素. 根据动力学实验, 当使用Fe-N-C-700催化剂时, 硝基苯加氢反应表观活化能为 $31.53 \mathrm{~kJ} / \mathrm{mol}$ (报道为 $91.5 \mathrm{~kJ} / \mathrm{mol})$, 这表明Fe-N-C-700催化剂可以有效地降低反应活化能.
\end{abstract}

关键词: 共热解; 铁; 氮掺杂; 碳材料; 氢化反应

收稿日期: 2019-04-28. 接受日期: 2019-05-27. 出版日期: 2019-10-05.

*通讯联系人. 电话: (0551)63603463; 传真: (0551)63606689; 电子信箱: zhzhying@ustc.edu.cn

†共同第一作者.

基金来源：国家自然科学基金(51876200, 21572213); 中国科学院洁净能源创新研究院合作基金(DNL180301).

本文的电子版全文由Elsevier出版社在ScienceDirect上出版(http://www.sciencedirect.com/science/journal/18722067). 